\title{
The Effect of Heat Treatment on Alkali Activated Materials
}

\author{
Girts BUMANIS ${ }^{1}$ *, Laura VITOLA ${ }^{1}$, Ana FERNANDEZ-JIMENEZ ${ }^{2}$, Angel PALOMO ${ }^{2}$, \\ Diana BAJARE ${ }^{1}$
}

\author{
${ }^{1}$ Department of Building Materials and Products, Riga Technical University, Kalku street 1, LV-1658, Riga, Latvia \\ ${ }^{2}$ Department of Cement and Materials Recycling, Eduardo Torroja Institute for Construction Science, c/ Serrano Galvache, \\ $n^{o}$ 4, 28033 Madrid, Spain \\ crossref http://dx.doi.org/10.5755/j01.ms.23.3.16280
}

Received 23 September 2016; accepted 06 December 2016

\begin{abstract}
The primary object of the present research was to investigate the porous low calcium alkali activated material (AAM). Traditionally $\mathrm{Na}+$ ions for alkali activation solution ensure highly alkaline media which enhances the dissolution of amorphous phase in the raw materials forming solid cementitious material with sodium aluminosilicate hydrate (N-A-S$\mathrm{H})$ structure afterwards. Almost all alkali ions are partially hydrated filling the pores in the gel structure (N-A-S-H gel, type zeolite precursor) and neutralizing the charge on $\mathrm{Al}(\mathrm{OH})^{-} 4$ groups. These alkali ions are available for leaching in water environment. Due to this property the application of porous AAM in this research is related to the water treatment systems similar to those of natural zeolites which are considered as effective sorbent because of their porous structure, high specific surface and ion exchange. Porous AAM was obtained from metakaolin, sodium silicate glass, modified sodium silicate solution with $\mathrm{Ms}=1.68$ and diethylene glycol (DEG) aluminium paste as pore forming agent. The density of AAM was $1150 \pm 12 \mathrm{~kg} / \mathrm{m}^{3}$ and compressive strength $f \mathrm{c}>12 \mathrm{MPa}$. The effect of heat treatment to microstructure and structural properties of AAM was investigated. Heat treatment is an effective method for changing the alkali leaching kinetic form AAM structure.

Keywords: alkali activated material, heat treatment, alkali leaching, water treatment.
\end{abstract}

\section{INTRODUCTION}

The quality of water resources is a major issue in the modern society due to the excessive increase in volumetric production of industrial and household wastewater and inadequate treatment of polluted water which could lead to the environmental problems. Traditionally heavy metals from wastewaters are removed using chemical precipitation, ion-exchange and electrochemical deposition which have many disadvantages such as high energy requirements and toxic sludge production during these processes [1]. The precipitation is considered to be a simple and effective method for wastewater treatment if low cost sorbents is used. It is considered that natural zeolites are effective sorbent material for separation and purification processes because of their porous structure and mobility of alkaline metals [2]. Also alkalizing agents, such as lime or caustic soda, have been used to raise the $\mathrm{pH}$ levels needed to induce chemical clarification of wastewaters, i.e. magnesium precipitation begins at approximately $\mathrm{pH} 9.5$, becomes significant above $\mathrm{pH} 10.5$, and is essentially complete at $\mathrm{pH}$ $11.0-11.5$. Good clarification is usually not achieved until $\mathrm{pH} 11.0-11.5$ is reached [3]. Flocculation at high $\mathrm{pH}$ media results in efficient removal of particles, colloids and certain dissolved materials present in the wastewater.

Natural zeolites could be altered with artificial alkali activated materials (AAM). AAM could be obtained from $\mathrm{Al}_{2} \mathrm{O}_{3}$ and $\mathrm{SiO}_{2}$ rich raw materials by using alkali activation technology [4]. Most common raw materials are metakaolin or fly ash which is activated with $\mathrm{NaOH}$ or sodium silicate solutions at relatively low temperature. The general formula for the reaction product is $2 \mathrm{SiO}_{2} \cdot \mathrm{Al}_{2} \mathrm{O}_{3} \cdot \mathrm{Na}_{2} \mathrm{O} \cdot 2 \mathrm{H}_{2} \mathrm{O}$ [5] which is expressed as $\mathrm{N}-\mathrm{A}-\mathrm{S}-\mathrm{H}$ gel ensuring good durability and mechanical properties [6-8]. The principle of AAM structure formation is given in Fig. 1. When sodium silicate solution with low Ms is used as activator, the solid material formed is amorphous and cementitious, but its structure and composition are different from the product, which is formed using only $\mathrm{NaOH}$. The amorphous $\mathrm{N}-\mathrm{A}-\mathrm{S}-\mathrm{H}$ gel has similar chemical composition as natural zeolite materials but without the extensive crystalline zeolite structure $[10,11]$. The optimal $\mathrm{SiO}_{2} / \mathrm{Al}_{2} \mathrm{O}_{3}$ ratio in the raw materials varies between 3.0 and 4.0 while $\mathrm{Na}_{2} \mathrm{O} / \mathrm{Al}_{2} \mathrm{O}_{3}$ ratio is around 1.0 [12].

Alkali activation solution ensures $\mathrm{Na}^{+}$ions and creates a strong alkaline media for the dissolution of amorphous phases from the raw materials. According to some authors $[13,14]$ the sodium taken up in these materials to balance the charge deficit in the gel structure, sodium can neutralize the negative charge in two ways: sodium associated with aluminium inside the gel structure (compensation of the charge deficit), more difficult to leaching and sodium partially hydrated that fills the pores in the gel structure, where it neutralizes the charge on $\mathrm{Al}(\mathrm{OH})^{-}{ }_{4}$ groups and must easy to exchange. More recently Skvara et al. have indicated that $\mathrm{Na}^{+}$ions are weakly bound in the nanostructure of the $\mathrm{N}-\mathrm{A}-\mathrm{S}-\mathrm{H}$ gel and therefore are almost completely leachable. $\mathrm{NaOH}$ easily diffuses to the surface, where it reacts with atmospheric $\mathrm{CO}_{2}$, while forming visible salts available for leaching, such as $\mathrm{Na}_{2} \mathrm{CO}_{3} \cdot \mathrm{nH}_{2} \mathrm{O}, \mathrm{NaHCO}_{3}$,

\footnotetext{
* Corresponding author. Tel.: +371-26062011; fax: +371-67089248.

E-mail address: girts.bumanis@rtu.lv(G. Bumanis)
} 
$\mathrm{K}_{2} \mathrm{CO}_{3}, \mathrm{KHCO}_{3}$ [15]. The leaching rate of $\mathrm{Na}^{+}$and $\mathrm{OH}^{-}$ from the AAM activated with $\mathrm{NaOH}$ or with sodium silicate solution is high for the first few weeks, decreasing over time [16]. A positive factor is the fact that alkalis could be leached out of the material structure without compromising its mechanical properties; therefore, this renders $\mathrm{Na}^{+}$as an unnecessary load-bearing element in the nanostructure of the $\mathrm{N}-\mathrm{A}-\mathrm{S}-\mathrm{H}$ gel and demonstrates $\mathrm{A}-\mathrm{S}-\mathrm{H}$ to be a loadbearing structure [15].

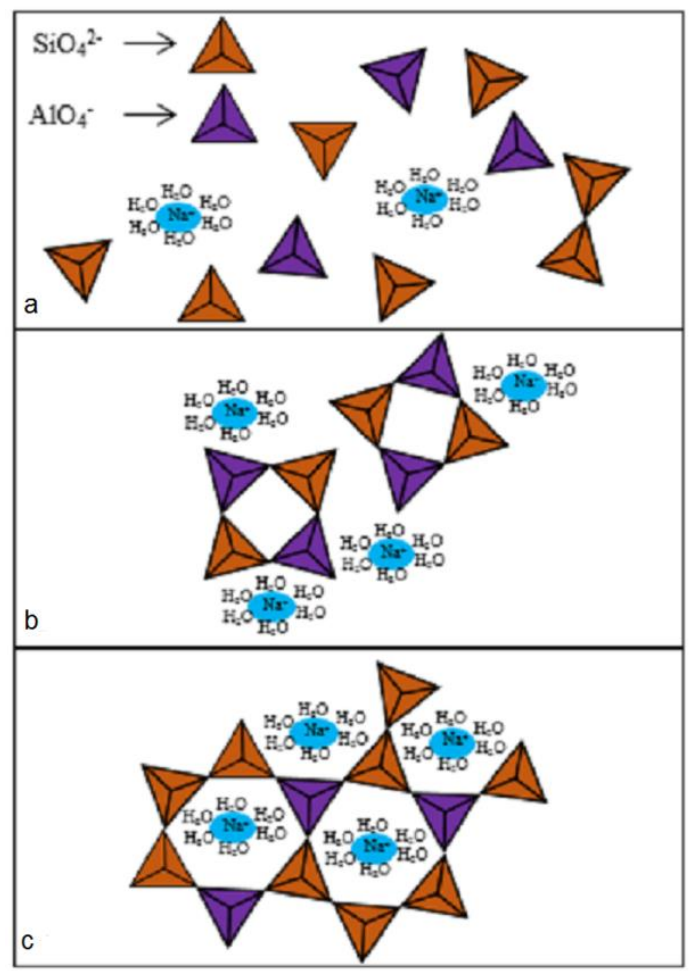

Fig. 1. Microstructure: a-aluminosilicate sources $+\mathrm{Na}+(\mathrm{aq})$, OH- (aq); b-N-A-S-H gel 1 (Si/Al 1); c-N-A-S-H gel 2 (3D) $(\mathrm{Si} / \mathrm{Al} 2)$ [9]

The porous structure of AAM would enclose alkalis inside the material structure resulting in a gradual alkali leaching over longer period of time. The porous structure ensures wider surface, where $\mathrm{Na}^{+}$ions can diffuse. Alkali release over a longer period of time is an advantage for using material in water treatment systems [17]. The porous material structure can be obtained by mixing gas-releasing agents like aluminium paste [18]. However, waste materials, like non-metallic residues from aluminium scrap recycling industry, can be used as well [19].

The DTA/TG analysis of AAM indicates that the heat treatment ensures loss of adsorbed water at $90{ }^{\circ} \mathrm{C}$. The loss of hydroxyl species depending on the alkaline element used for the synthesis proceeds at around $200^{\circ} \mathrm{C}$ and the loss of structural water from crystalline structure - at around $400-500{ }^{\circ} \mathrm{C}$ [20]. The dehydration reaction could affect properties of the material in water media and hydration reaction occur to reattach the lost water therefore affecting leaching properties in water media.

The present paper suggests using low-calcium AAM obtained by alkali activation technology as the passive system for stabilization of the $\mathrm{pH}$ (pH 10 to 11) in the water treatment systems. The effect of heat treatment on the structure of AAM and leaching properties were studied. The prepared AAM was amorphous to semi-crystalline material that is formed by transformation of metakaolin and sodium silicate glass raw materials with sodium silicate solution at low temperature in a very short time.

\section{EXPERIMENTAL DETAILS}

Porous alkali activated material (AAM) was created using metakaolin (MK) and sodium silicate glass (SSG) activated with modified sodium silicate solution (Ms 1.67) (activator). Activator was prepared using sodium silicate solution with Ms 3.22 and sodium hydroxide flakes with the mass ratio 9:1. Suspension of the diethylene glycol aluminium paste (AlP) mixed with $\mathrm{H}_{2} \mathrm{O}$ was used as a pore structure forming agent (mass ratio 1:5). The chemical composition of raw materials is given in Table 1.

Table 1. Chemical composition of raw materials

\begin{tabular}{|c|c|c|c|c|}
\hline \multirow{2}{*}{ Compound } & \multicolumn{4}{|c|}{ Amount, wt.\% } \\
\cline { 2 - 5 } & MK & SSG & Activator & AlP \\
\hline $\mathrm{SiO}_{2}$ & 57.2 & 76.1 & 25.1 & - \\
\hline $\mathrm{Al}_{2} \mathrm{O}_{3}$ & 33.9 & 2.8 & - & - \\
\hline $\mathrm{TiO}_{2}$ & 2.9 & - & - & - \\
\hline $\mathrm{Fe}_{2} \mathrm{O}_{3}$ & 1.5 & 0.1 & - & - \\
\hline $\mathrm{CaO}$ & 0.3 & - & - & - \\
\hline $\mathrm{MgO}$ & 0.4 & - & - & - \\
\hline $\mathrm{Na}_{2} \mathrm{O}$ & 0.3 & 21.0 & 11.6 & - \\
\hline $\mathrm{K}_{2} \mathrm{O}$ & 2.7 & - & - & - \\
\hline $\mathrm{Al}$ & - & - & - & 13.8 \\
\hline
\end{tabular}

The mixture composition of AAM is given in Table 2. The electrical hand mixer was used for controlled mixing. All dry raw materials were mixed for 15 seconds, then activator was added to the mixture and mixed for 2 minutes until homogenous paste was obtained. Suspension of AlP was added to the paste to create porous structure and mixed for 10 seconds. Right after the mixing, paste was casted into sealed prismatic moulds measuring $40 \times 40 \times 160 \mathrm{~mm}$. Moulds were placed in a room temperature $\left(20 \pm 2{ }^{\circ} \mathrm{C}\right)$ for 20 minutes to provide pore formation. Then the moulds were covered with plastic film and cured at $80{ }^{\circ} \mathrm{C}$ for $24 \mathrm{~h}$. The prepared samples will be referred as A10-T-SSG1 further in the text. After demoulding the following physical properties of the prepared porous AAM samples were tested in accordance with EN 1097-6 and EN 1097-7: bulk density, water absorption (wt.\%), open and total porosity (vol.\%). The heat treated samples were prepared at $200{ }^{\circ} \mathrm{C}$ for $3 \mathrm{~h}$ with heating rate $10{ }^{\circ} \mathrm{C} / \mathrm{min}$ and will be referred as A10-T-SSG1-200 further in the text.

$\mathrm{Na}^{+}$ion exchange in water media was determined by using titration method. Alkalis hydrated within the pores of the gel, more weakly bound, are exchanged; in this case with the water protons $\left(\mathrm{Na}^{+}\right.$ion is exchanged for a $\mathrm{H}^{+}$ion). The phenomena resulted in an increased alkalinity of the medium. The $\mathrm{pH}$ of water solution after $24 \mathrm{~h}$ immersion of the prepared AAM (weight $3.0 \pm 0.2 \mathrm{~g}$ ) in the $100 \mathrm{ml}$ of deionized water was determined with portable $\mathrm{pH} / \mathrm{mV}$ meter HI 991003 with sensor check. Samples were moved to the new batch with deionized water $(100 \mathrm{ml})$ every $24 \mathrm{~h}$. Obtained leachate was titrated to determine $\mathrm{OH}^{-}$group in $\left(\mathrm{OH}-\mathrm{mol} \cdot(\mathrm{l} \cdot \mathrm{g})^{-1}\right)$ with hydrochloric acid $0.01 \mathrm{M}$ to $\mathrm{pH} 7.0$ for determination alkalinity. 
Table 2. Mixture composition of AAM

\begin{tabular}{|c|c|}
\hline Compound & $\begin{array}{c}\text { A10-T-SSG1 } \\
\text { composition, mass ratio }\end{array}$ \\
\hline Suspension of AlP & 0.02 \\
\hline MK & 1 \\
\hline SSG & 1 \\
\hline Activator & 1.3 \\
\hline Activator to solid ratio & 0.65 \\
\hline $\mathrm{SiO}_{2} / \mathrm{Al}_{2} \mathrm{O}_{3}$ & 4.5 \\
\hline $\mathrm{Na}_{2} \mathrm{O} / \mathrm{Al}_{2} \mathrm{O}_{3}$ & 1.0 \\
\hline
\end{tabular}

The thermogravimetric-differential thermal analysis (DTA/TG) was carried out by using Stanton Redcroft STA 781 thermal analyser from $0{ }^{\circ} \mathrm{C}$ to $700{ }^{\circ} \mathrm{C}$ at a heating rate of $5^{\circ} \mathrm{C} / \mathrm{min}$. The mineralogical and microstructural characteristics of the obtained material before and after heat treatment, as well as before and after leaching test were studied with FTIR, XRD and SEM/EDX., ATIMATTSON FTIR-TM was used to obtain FTIR spectra. Test specimens were prepared by mixing $300 \mathrm{mg}$ of $\mathrm{KBr}$ with $1 \mathrm{mg}$ of AAM sample. The spectral analysis was performed in a range from 2000 to $400 \mathrm{~cm}^{-1}$. The crystalline phases of material before and after treatments were identified with XRD BRUKERAXS D8 ADVANCE X-ray diffractomer and collected with $\mathrm{CuK} \alpha 1, \alpha 2$ radiation in the range $5-60^{\circ}(2 \theta)$. JEOL JSM 5400 scanning electron microscope (SEM) with LINK-ISIS energy dispersive analyser (EDX) was used for the microstructural characterization.
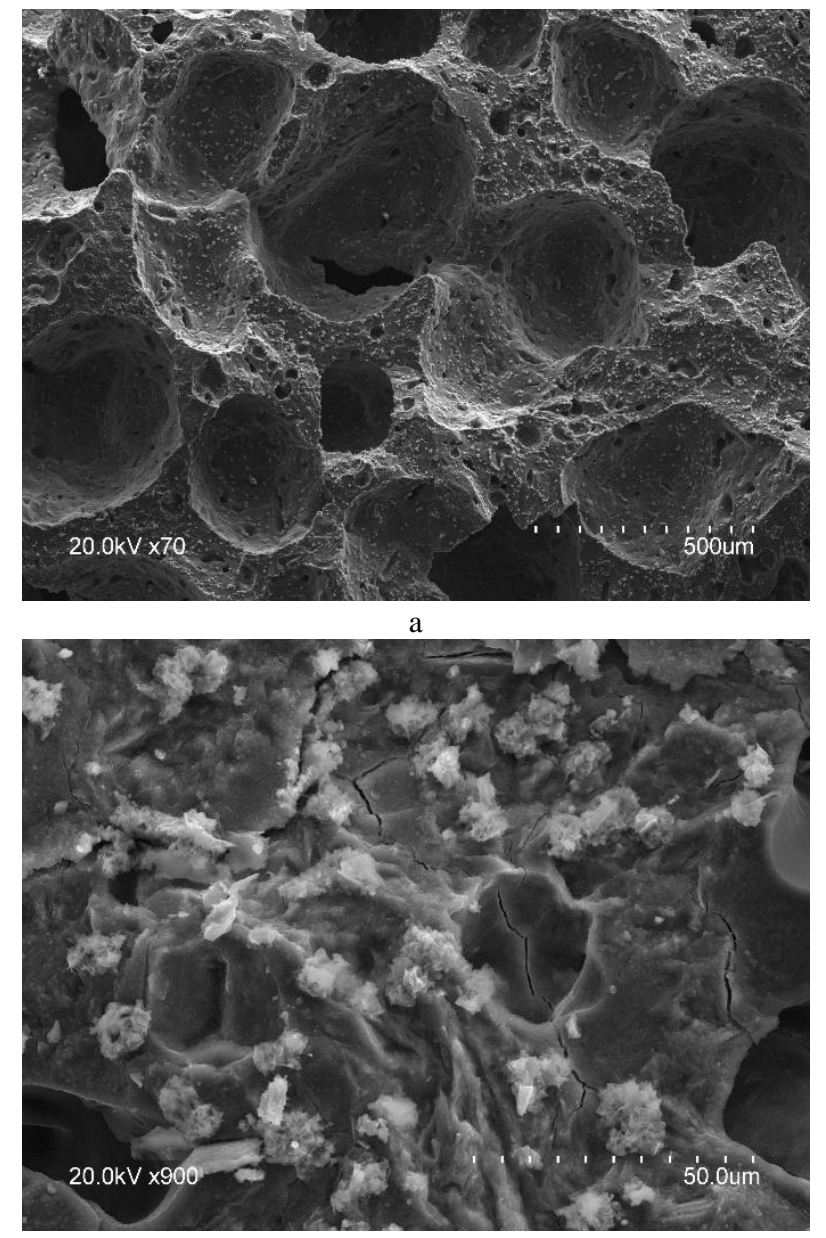

c

\section{RESULTS}

Physical properties of the prepared AAM A10-T-SSG1 are given in Table 3. The macro- and microstructure of AAM is given in Fig. 2. The porous structure of the obtained samples is similar to those of aerated autoclaved concrete. A10-T-SSG1 and A10-T-SSG1-200 have homogenous macro pore structure with pore size ranging from 200 to $600 \mu \mathrm{m}$ (Fig. 2). Micro level pores with size up to $50 \mu \mathrm{m}$ were detected. The crystalline substances were observed on the surface of pore walls and inside the structure (broken cross-sections) (Fig. 2 b). The size of these crystalline substances was $10 \mu \mathrm{m}$. EDX results indicate that these substances contain high amount of $\mathrm{Na}(35-40 \mathrm{wt} . \%)$ and $\mathrm{O}$ (37-40 wt.\%), Si (14-20 wt.\%) and Al (3-9 wt.\%). After the heat treatment at $200{ }^{\circ} \mathrm{C}$ (A10-T-SSG1-200) the macro scale changes were not observed (Fig. 2 c). The size of previously observed crystalline substances (found on the pore surface Fig. 2 d) decreased from $10 \mu \mathrm{m}$ to $1-5 \mu \mathrm{m}$.

Table 3. Physical and mechanical properties of AAM (A10-T-SSG1)

\begin{tabular}{|l|c|}
\hline \multicolumn{1}{|c|}{ Property } & Result \\
\hline Bulk density, $\mathrm{kg} / \mathrm{m}^{3}$ & $1150 \pm 12$ \\
\hline Water absorbtion, wt.\% & $9.5 \pm 0.5$ \\
\hline Open porosity, vol.\% & $10.6 \pm 0.8$ \\
\hline Total porosity, vol.\% & $57.5 \pm 0.5$ \\
\hline Compressive strength, $\mathrm{MPa}$ & $12.8 \pm 1.2$ \\
\hline
\end{tabular}

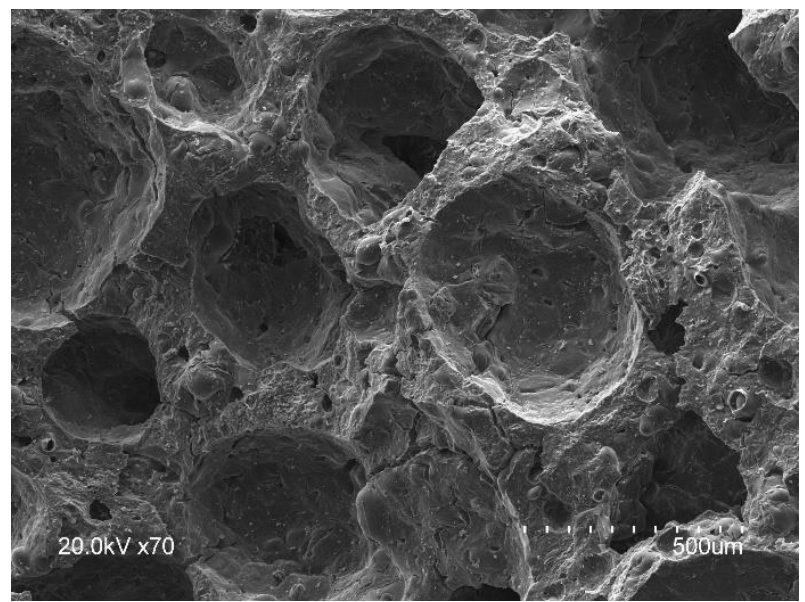

b

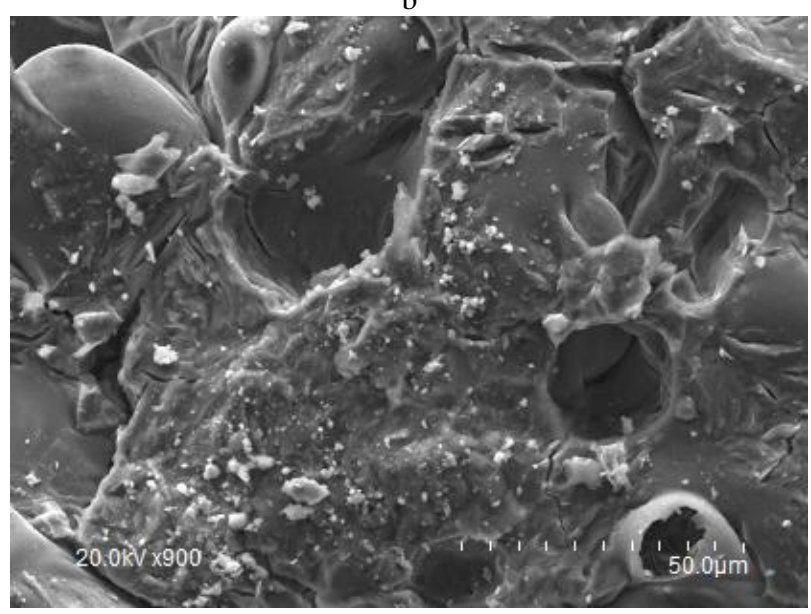

d

Fig. 1. Microstructure of prepared samples: a and c-AAM A10-T-SSG1; b and d-heat treated AAM A10-T-SSG1-200 
DTA/TG results indicate that the prepared AAM A10-T-SSG1 has endothermic peak at around of 100 to $120^{\circ} \mathrm{C}$ and small endothermic effect at around $200^{\circ} \mathrm{C}$ (Fig. 3). TG curve shows even weight loss during heating resulting in $95.3 \%$ at $400{ }^{\circ} \mathrm{C}$. To study this endothermic effect, AAM was heated at $200{ }^{\circ} \mathrm{C}$ for $3 \mathrm{~h}$ (A10-T-SSG1200). Afterwards DTA/TG was repeated and previously detected peaks below $200{ }^{\circ} \mathrm{C}$ were not detected.

After 10 days leaching test DTA/TG analyses were repeated for both the heat-treated and untreated samples (A10-T-SSG1-AL and A10-T-SSG1-200-AL). The endothermic effect at around $110^{\circ} \mathrm{C}$ was still detected while at $200{ }^{\circ} \mathrm{C}$ it diminished. It was detected that the weight loss at $120{ }^{\circ} \mathrm{C}$ for A10-T-SSG1-AL was $6 \%$ while for A10-TSSG1-200-AL-2.5\% (Fig. 4). At $200{ }^{\circ} \mathrm{C}$ the weight loss increased to $11 \%$ and $4.5 \%$ respectively.

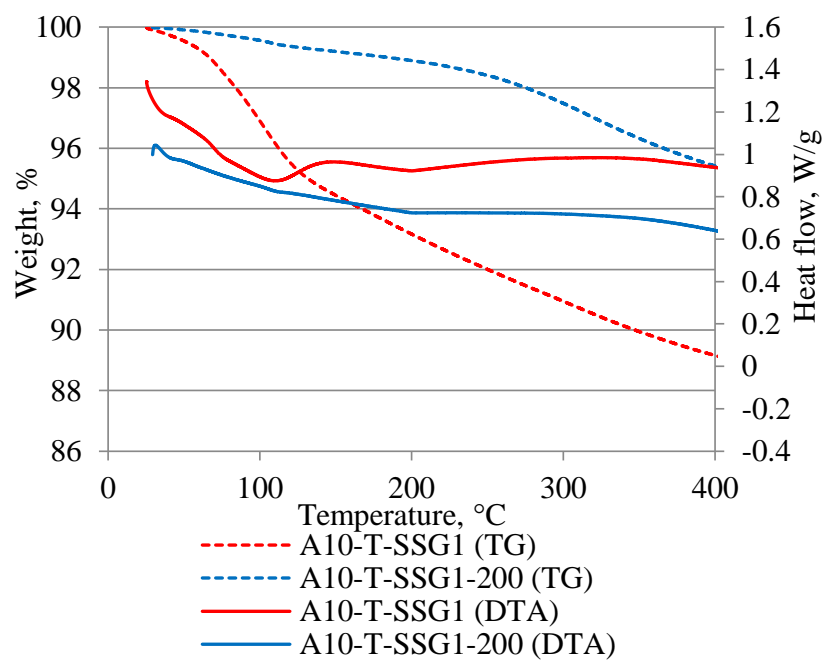

Fig. 2. DTA/TG results of prepared A10-T-SSG1 and A10-T-SSG1-200

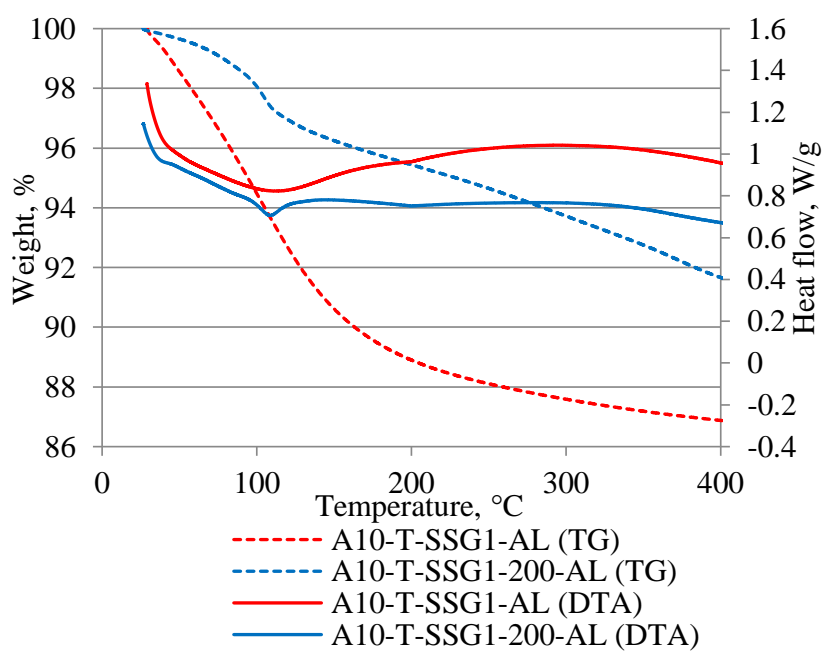

Fig. 3. DTA/TG results of AAM after leaching test (A10-T-SSG1-AL and A10-T-SSG1-200-AL)

Structural changes in macro and micro level after the heat treatment were not detected. Both heat-treated and untreated samples were tested on alkali leaching kinetic form AAM structure (Fig. 5). It was observed that the untreated sample provides two times higher alkali leaching rate comparing to the sample treated at $200{ }^{\circ} \mathrm{C}$ (Fig. 5). The alkali leaching in both cases was gradual with slight trend to lower leaching intensity by the increase of leaching time. After 10 day leaching untreated AAM the sum of alkalinity was $0.026 \mathrm{OH}-\mathrm{mol} \cdot(\mathrm{l} \cdot \mathrm{g})^{-1}$ while the heat treatment reduced leaching more than 2 times and was $0.012 \mathrm{OH}-\mathrm{mol} \cdot(\mathrm{l} \cdot \mathrm{g})^{-1}$. The initial $\mathrm{pH}$ level depending from the heat treatment was $\mathrm{pH} 11.9$ for A10-T-SSG1 and $\mathrm{pH} 11.7$ for A10-T-SSG1200. Gradual $\mathrm{pH}$ decrease was observed for A10-T-SSG1 and after 10 days leaching period $\mathrm{pH}$ decreased to $\mathrm{pH} 9.9$. The heat-treated sample (A10-T-SSG1-200) showed initial $\mathrm{pH}$ decrease up to $5^{\text {th }}$ day reaching $\mathrm{pH} 11.2$ and remained constant up to the $10^{\text {th }}$ day.

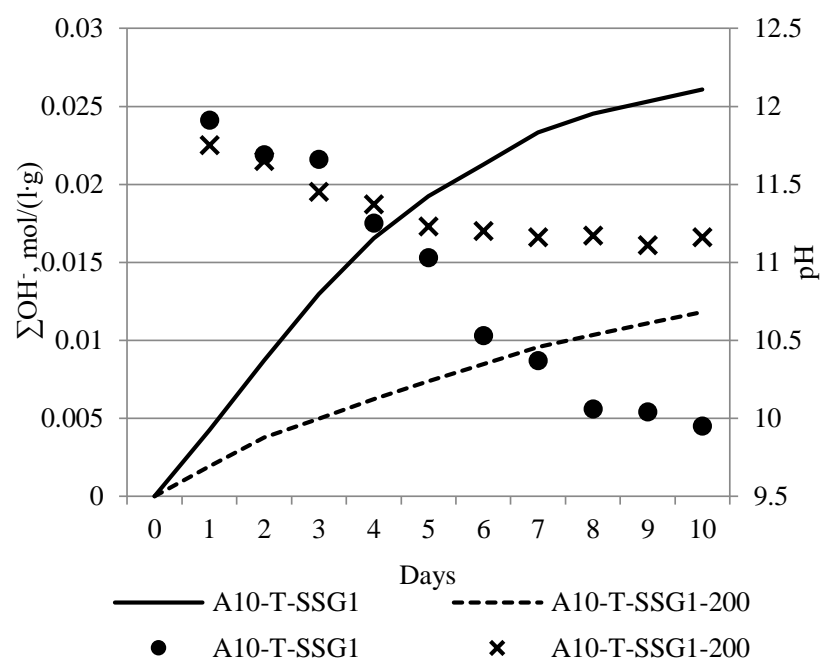

Fig. 4. Cumulative leaching rate of $\mathrm{OH}^{-}$ions and $\mathrm{pH}$ level during leaching test of A10-T-SSG1 and A10-T-SSG1-200

EDX analysis indicates that the element changes in the structure of AAM samples (Table 4). 15 to 30 spectral points for each element were analysed. The heat treatment did not change elemental analysis significantly (A10-TSSG1 and A10-T-SSG1-200): $\mathrm{Al}$ was $6.8 \mathrm{wt} \%$, Na 14.9-15.1 wt.\%, Si 30.4-32.2 wt.\% and $\mathrm{O}$ from 45.6 to 46.7 wt. \% respectively. After 10 days leaching the element relation changed and the amount of $\mathrm{Na}$ reduced noticeably to $5.7 \mathrm{wt} . \%$ for A10-T-SSG1-AL and to $9.2 \mathrm{wt} . \%$ for A10-T-SSG1-200-AL. The amount of Si and O remained approximately in the same level. This means that a large part of sodium leached as indicated by Skvara et al. [15]. Sodium that still remains in the matrix could be leached over time; however according to Duxson et al and Criado et al a small amount could be retained as a part of the gel N-A-S-H [15], [25]. Studies at a later leaching age would be needed to clarify this issue.

Table 4. EDX element analysis of AAM at different treatment regimes

\begin{tabular}{|c|c|c|c|c|}
\hline \multirow{3}{*}{ Element } & \multicolumn{4}{|c|}{ Amount, wt.\% } \\
\cline { 2 - 5 } & $\begin{array}{c}\text { A10-T- } \\
\text { SSG1 }\end{array}$ & $\begin{array}{c}\text { A10-T- } \\
\text { SSG1-200 }\end{array}$ & $\begin{array}{c}\text { A10-T- } \\
\text { SSG1-AL }\end{array}$ & $\begin{array}{c}\text { A10-T-SSG1- } \\
\text { 200-AL }\end{array}$ \\
\hline $\mathrm{O}$ & $45.6 \pm 3.0$ & $46.7 \pm 1.5$ & $48.9 \pm 2.0$ & $46.7 \pm 3.4$ \\
\hline $\mathrm{Na}$ & $14.9 \pm 2.9$ & $15.1 \pm 3.4$ & $5.7 \pm 1.3$ & $9.2 \pm 2.1$ \\
\hline $\mathrm{Al}$ & $6.8 \pm 2.1$ & $6.8 \pm 2.6$ & $11.3 \pm 2.1$ & $8.5 \pm 2.6$ \\
\hline $\mathrm{Si}$ & $30.4 \pm 4.1$ & $32.2 \pm 3.6$ & $31.5 \pm 3.0$ & $32.3 \pm 4.1$ \\
\hline
\end{tabular}

The FTIR spectra are given in Fig. 6. The bands between $1017-1076 \mathrm{~cm}^{-1}$ are characteristic for the internal vibrations in aluminosilicates associated with $\mathrm{T}-\mathrm{O}(\mathrm{T}=\mathrm{Al}$, 
Si) asymmetric stretching vibrations. This band moves to lower frequencies in AAM, which is associated to the formation of a N-A-S-H gel [21]. However, in the leaching process it returns to slightly higher frequencies. The intensity of the band at $452-465 \mathrm{~cm}^{-1}$, associated in all cases with $\mathrm{T}-\mathrm{O}$ bending vibrations, barely changes its position throughout the activation process $[22,23]$. This band provides an indication of the degree of "amorphisation" of the material, since its intensity does not depend on the degree of crystallisation. The band appearing at $780-790 \mathrm{~cm}^{-1}$ corresponds to the quartz doublet present in the original MK. The band at $558 \mathrm{~cm}^{-1}$ corresponds to the $\mathrm{Si}-\mathrm{O}-\mathrm{Al}^{\mathrm{VI}}$ vibrations in dehydroxylated muscovite [24], the intensity of this band decrease in AAM, indicating that this phase shows weak reaction, which probably could be explained with the dihydroxylation. The aluminum coordination environment in the $\left(\mathrm{AlO}_{6}\right)$ octahedron gradually changed to five-coordination leading to the relaxation of the crystal and increase of its reactivity. Intense $\mathrm{C}-\mathrm{O}$ band asymmetric stretching vibration band appeared at $1451 \mathrm{~cm}^{-1}$ [21] for sample A10-T-SSG1, while for sample A10-T-SSG1-200 this band absorption intensity decreased and for samples after leaching (A10-T-SSG1-AL and A10-T-SSG1-200-AL) did not appear at all. This band is associated to the present of a little sodium carbonate that has been solubility in the leaching process.

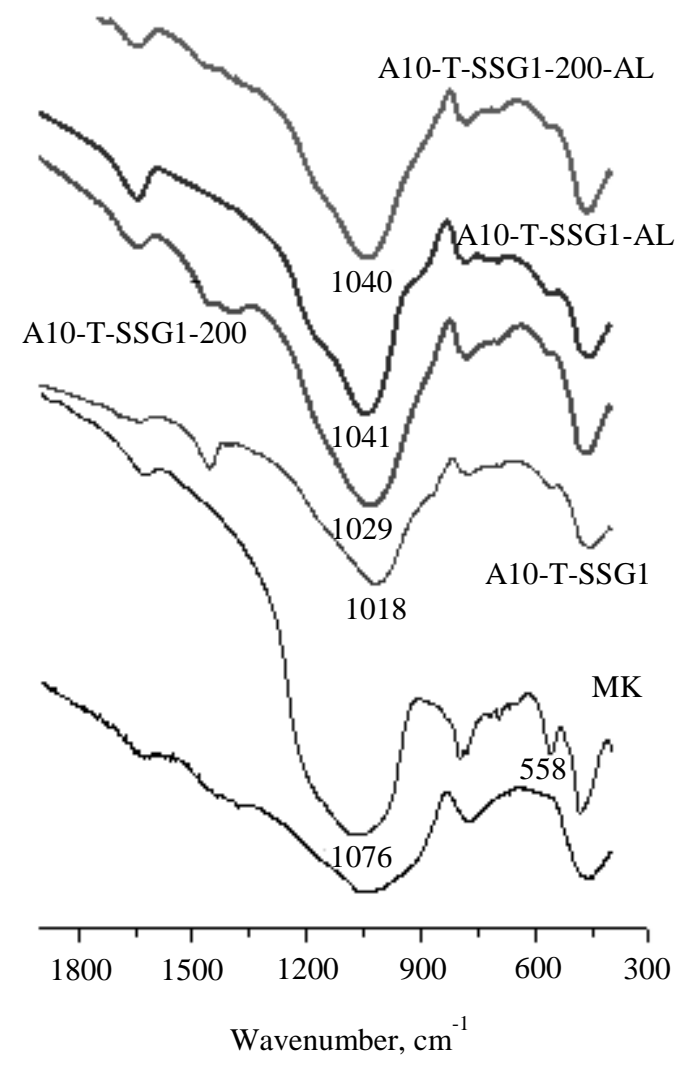

Fig. 5. FTIR analysis for raw materials and samples (absorption spectra)

Results of the X-ray diffraction analysis for raw materials and obtained samples are given in Fig. 7. The halo present in SSG diffractogram in the $20-30^{\circ} 2 \theta$ intervals is indicative of vitreous component, in MK diffractogram a hump is also observed associated to the structurally disordered phase such as metakaolinite. Some minor crystalline phases were detected in $\mathrm{MK}$ : quartz $\left(\mathrm{SiO}_{2}\right)$, mica $\mathrm{KAl}_{3} \mathrm{Si}_{3} \mathrm{O}_{11}$ and muscovite $\left(\mathrm{K}_{0.82} \mathrm{Na}_{0 \cdot 18}\right)\left(\mathrm{Fe}_{0.03} \mathrm{Al}_{1.97}\right)$. In the obtained AAM the halo shifts to higher $2 \theta$ values, which indicates the formation of $\mathrm{N}-\mathrm{A}-\mathrm{S}-\mathrm{H}$ gel [25] and has the halo in the $2 \theta=15-40^{\circ}$ region, which is typical also for the A10-T-SSG1-200 and samples after leaching test (A10-TSSG1-AL and A10-T-SSG1-200-AL). The crystalline muscovite peaks were not detected in AAM after alkali activation. Other crystalline materials from MK such as quartz remained in AAM after alkali activation.

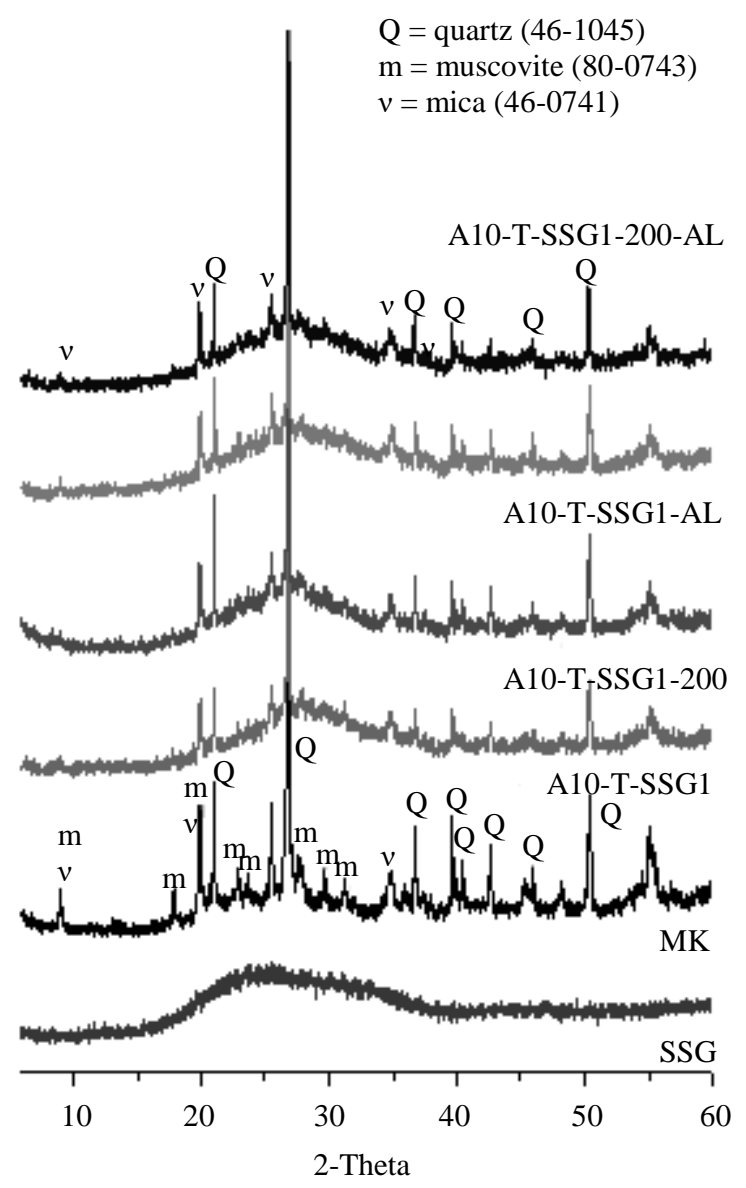

Fig. 6. XRD diffractograms of raw materials and prepared AAM samples

\section{DISCUSSION}

Porous AAM with the bulk density of $1150 \mathrm{~kg} / \mathrm{m}^{3}$ was obtained using AlP as pore forming agent and the bulk density of material ensures material that does not float in water. The low open porosity $(9.5 \mathrm{wt} . \%)$ and water absorption (10.6 vol.\%) provides gradual water penetration into the structure of AAM; therefore, ion exchange could be reduced comparing to the materials with high open porosity around $30 \%$ [26]. However, the fractioned AAM with open pore structure and increased surface could be prepared to enhance leaching [27]. The compressive strength of 12.8 $\mathrm{MPa}$ allows to use this material in water treatment systems with pressure up to 1 bar without damaging the AAM matrix. 
Two distinct endothermic peaks in A10-T-SSG1 were detected in the DTA spectra. The first endothermic peak appeared at $110^{\circ} \mathrm{C}$, while the second peak appeared at $190{ }^{\circ} \mathrm{C}$. The first endothermic peak was primarily caused by the dissipation of free water from the AAM surface. The water evaporated within this temperature range, and similar behavior was observed by Cheng et al [28]. The second endothermic peak was attributed to the presence of zeolitic water in the reaction products, water bonding tightly with $\mathrm{AAM}$, or water needing higher temperature to reach the surface of AAM [29]. The weight loss of A10-T-SSG1 was $4.0 \%$ at $120{ }^{\circ} \mathrm{C}$ and increased to $7 \%$ at $200{ }^{\circ} \mathrm{C}$ whereas heat treated AAM (A10-T-SSG1-200) had weight loss of only $0.5 \%$ at $120{ }^{\circ} \mathrm{C}$ and $0.8 \%$ at $200{ }^{\circ} \mathrm{C}$ according to TG analysis. Heat treatment effectively removed free water which could retard ion exchange due to the low hydration process, which takes place after immersing material into the water. This effect was detected by DTA/TG after the 10 day, leaching test in water. After leaching DTA/TG was repeated and it was observed that two endothermic effects remained for both treated and untreated AAM (A10-T-SSG1-AL and A10-T-SSG1-200-AL). The weight loss was $6 \%$ at $120^{\circ} \mathrm{C}$ and $11 \%$ at $200{ }^{\circ} \mathrm{C}$ for A10-T-SSG1-AL, while for A10-TSSG1-200-AL the weight loss was $2.5 \%$ and $4.5 \%$ respectively. The 10 day, immersing period increased the amount of water hydrated in the structure of AAM; therefore weight loss increased.

The leaching test reveals the importance of AAM heat treatment on ion exchange kinetics. Untreated AAM (A10T-SSG1) with attached alkaline crystalline substances on pore surface (Fig. 2) provides high initial $\mathrm{pH}$; however, over the time $\mathrm{pH}$ decreases and amount of $\mathrm{Na}$ in structure of AAM decreases which was detected with EDX (Table 4). The ion exchange trend line also declines to reduced leaching intensity at the end of the leaching test. Sample A10-T-SSG1-200 has lower leaching rate comparing to A10-T-SSG1; however, the leaching process is more gradual and stabilizes over time and the $\mathrm{pH}$ level of leachate becomes predictable at value $\mathrm{pH}$ 11.2. According to EDX more $\mathrm{Na}$ remains in the structure after leaching test which indicates the long lasting alkali leaching properties. Also EDX indicated that heat treatment did not affect the amount of $\mathrm{Si}, \mathrm{O}, \mathrm{Na}, \mathrm{Al}$ in the structure of AAM, while AAM after leaching provided reduced amount of $\mathrm{Na}$ and increased amount of $\mathrm{Al}$.

The FTIR spectra of A10-T-SSG1 shows that N-A-S-H gel formation has occurred (Fig. 6) [23, 30]. The absorption shoulder shift to higher frequencies indicates the bond transformation and alkali activation of raw materials. The heat treatment of AAM removes the $\mathrm{C}-\mathrm{O}\left(\mathrm{CO}_{3}{ }^{2-}\right)$ bond absorption spectra at $1451 \mathrm{~cm}^{-1}$ which could indicate the decomposition of bicarbonates and carbonates such as $\mathrm{NaHCO}_{3}$ (decomposition temperature 100 to $200{ }^{\circ} \mathrm{C}$ ). The effect of leaching has narrowed the absorption band shoulder for both AAM and this phenomenon should be investigated more closely.

The obtained AAM is ,X-ray amorphous" demonstrated by the halo in the $2 \theta=15-40^{\circ}$ region that is usually described as geopolymeric gels formation [31]. Substantial impact of the heat treatment and leaching on obtained material was not detected by XRD.

\section{CONCLUSIONS}

DTA/TG analysis indicate that the heat treatment of $\mathrm{AAM}$ at $200{ }^{\circ} \mathrm{C}$ removes free water from the structure of AAM; therefore, the hydration time increases, when AAM is subjected to the water and this effectively reduces ion exchange and the exchange rate is even.

The heat treatment has an important role regarding the leaching rate and $\mathrm{pH}$ changes of the leachate. The heattreated materials provide even leaching rate at least 10 days and $\mathrm{pH}$ level stabilizes after 5 leaching days reaching $\mathrm{pH}$ 11.2 which remained constant over a period of up to 10 days, while the $\mathrm{pH}$ level of untreated AAM decreases and ion exchange rate was up to 3.2 times higher compared to heattreated AAM.

The content of $\mathrm{Na}$ decreases in the structure of AAM during leaching. This would allow predicting the effective leaching time of the material during its immersion into the water, where duration of leaching for the heat-treated material would be considerably longer.

FTIR and XRD analysis did not indicate substantial changes of AAM structure during the heat treatment and leaching confirming that $\mathrm{Na}$ leaching is bound to the structure with weak bonds.

The use of heat treated AAM would be preferable in water treatment systems due to the prolonged leaching period and more stable $\mathrm{pH}$ level during leaching.

\section{Acknowledgments}

This work was supported by the Latvian Council of Science Fund Project Z12.0491 "Smart biofiltration technology" and also by the Spanish Ministry of the Economy and Competitiveness under the projects BIA201343293-R.

\section{REFERENCES}

1. Bailey, S.E, Olin, T.J., Bricka, R.M., Adrian, D.D. A Review of Potentially Low-Cost Sorbents for Heavy Metals Water Research 33 (11) 1999: pp. 2469-2479.

2. He, Y., Cui, X., Liu, X., Wang, Y., Zhang, J., Liu, K. Preparation of Self-Supporting Naa Zeolite Membranes Using Geopolymers Journal of Membrane Science 447 2013: pp. $66-72$. https://doi.org/10.1016/j.memsci.2013.07.027

3. Semerjian, L., Ayoub, G. M. High-pH-Magnesium Coagulation-Flocculation in Wastewater Treatment Advances in Environmental Research 7 (2) 2003: pp. 389-403.

4. Juenger, M.C.G., Winnefeld, F., Provis, J.L., Ideker, J.H. Advances in Alternative Cementitious Binders Cement and Concrete Research 41 (12) 2001: pp. 1232-1243. https://doi.org/10.1016/j.cemconres.2010.11.012

5. Li, C., Sun, H., Li, L. A review: The Comparison Between Alkali-Activated Slag $(\mathrm{Si}+\mathrm{Ca})$ and Metakaolin $(\mathrm{Si}+\mathrm{Al})$ Cements Cement and Concrete Research 40 (9) 2010: pp. $1341-1349$.

https://doi.org/10.1016/j.cemconres.2010.03.020

6. Alonso, S., Palomo, A. Alkaline Activation of Metakaolin and Calcium Hydroxide Mixtures: Influence of Temperature, Activator Concentration and Solids Ratio Materials Letters 47 (1-2) 2001: pp. 55-62. 
7. Williams, I., van Riessen, A. Thermal Barriers Applied Clay Science 46 (3) 2009: pp. 6-11.

8. Temuujin, J., van Riessen, A., Williams, R. Influence of Calcium Compounds on The Mechanical Properties of Fly Ash Geopolymer Pastes Journal of Hazardous Materials 167 (1-3) 2009: pp. 82-88. https://doi.org/10.3989/mc.2014.00314

9. Palomo, A., Krivenko, P., Garcia-Lodeiro, I., Kavalerova, E., Maltseva, O., Fernandez-Jimenez, A. A Review on Alkaline Activation: New Analytical Perspectives Materiales de Construccion 64 (315) 2014: p. e022.

10. Rowles, M.R., O'Connor, B.H. Chemical and Structural Microanalysis of Aluminosilicate Geopolymers Synthesized by Sodium Silicate Activation of Metakaolinite Journal of the American Ceramic Society $92(10)$ 2009: pp. 2354-2361.

11. Bernal, S. A., de Gutierrez, R.M.M., Provis, J.L., Rose, V. Effect of Silicate Modulus and Metakaolin incorporation on the carbonation of alkali silicate-activated slags Cement and Concrete Research 40 (6) 2010: pp. 898-907. https://doi.org/10.1016/j.cemconres.2010.02.003

12. Garcia-Lodeiro, I., Fernandez-Jimenez, A., Pena, P., Palomo, A. Alkaline Activation of Synthetic Aluminosilicate Glass Ceramics International 40 (4) 2014: pp. $5547-5558$.

13. Duxson, P., Lukey, G.C., Separovic, F., Van Deventer, J.S.J. Effect of Alkali Cations on Aluminum Incorporation in Geopolymeric Gels Industrial and Engineering Chemistry Research 44 (4) 2005: pp. $832-839$.

14. Provis, J.L., van Deventer, J.S.J. Geopolymers. Structures, Processing, Properties and Industrial Applications, Woodhead Publishing, UK, 2009: p. 464.

15. Skvara, F., Smilauer, V., Hlavacek, P., Kopecky, L., Cílova, Z. A Weak Alkali Bond in (N, K)-A-S-H Gels: Evidence from Leaching and Modeling Ceramics - Silikaty 56 (4) 2012: pp. 374-382.

16. Aly, Z., Vance, E.R., Perera, D.S., Hanna, J.V., Griffith, C.S., Davis, J., Durce, D. Aqueous Leachability of Metakaolin-Based Geopolymers with Molar Ratios of $\mathrm{Si} / \mathrm{Al}=1.5-4 \quad$ Journal of Nuclear Materials 378 (2) 2008: pp. $172-179$. https://doi.org/10.1016/j.jnucmat.2008.06.015

17. Rugele, K., Bumanis, G., Erina, L., Erdmane, D. Composite Material for Effective Cheese Whey Anaerobic Digestion Key Engineering Materials 604 2014: pp. 236-239.

18. Zhang, Z., Provis, J.L., Reid, A., Wang, H. Geopolymer foam Concrete: An Emerging Material for Sustainable Construction Construction and Building Materials 56 2014: pp. 113-127.

https://doi.org/10.1016/j.conbuildmat.2014.01.081

19. Bajare, D., Korjakins, A., Kazjonovs, J., Rozenstrauha, I. Pore Structure of Lightweight Clay Aggregate Incorporate with Non-Metallic Products Coming from Aluminium Scrap Recycling Industry Journal of the European Ceramic Society 32 (1) 2012: pp. $141-148$.
20. Prud'homme, E.,

Michaud, P.,

Joussein, E., Clacens, J.M., Arii-Clacens, S., $\quad$ Sobrados, I., Peyratout, C., Smith, A., Sanz, J., Rossignol, S. Structural Characterization of Geomaterial Foams - Thermal Behavior Journal Non-Crystalline Solids 357 (21) 2011: pp. $3637-3647$. https://doi.org/10.1016/j.jnoncrysol.2011.06.033

21. Garcia-Lodeiro, I., Fernandez-Jimenez, A., Blanco, M.T., Palomo, A. FTIR Study of the Sol-Gel Synthesis of Cementitious Gels: C-S-H and N-A-S-H Journal Sol-Gel Science and Technology 45 (1) 2008: pp. 63-72. https://doi.org/10.1007/s10971-007-1643-6

22. Sayin, M., Von Reichenbach, H.G. Infrared Spectra of Muscovites as Affected by Chemical Composition Heating and Particle Size Clay Minerals 13 (241) 1978: pp.241254.

23. Lee, W.K.W., Van Deventer, J.S.J. Use of Infrared Spectroscopy to Study Geopolymerization of Heterogeneous Amorphous Aluminosilicates Langmuir 19 (21) 2003: pp. 8726-8734.

24. Tang, J., Zhang, Y., Bao, S. The Influence of Roasting Temperature on the Flotation Properties of Muscovite Minerals 6(2) 53 2016: pp. 1-9.

25. Criado, M., Fernandez-Jimenez, A., de la Torre, A.G., Aranda, M.A.G., Palomo, A. An XRD Study of the Effect of the $\mathrm{SiO} 2 / \mathrm{Na} 2 \mathrm{O}$ Ratio on the Alkali Activation if Fly Ash Cement and Concrete Research 37 2007: pp. 671-679. https://doi.org/10.1016/j.cemconres.2007.01.013

26. Bajare, D., Bumanis, G. Alkali Diffusion in Porous Alkali Activated Materials International Conference on NonTraditional Cement and Concrete 2014: pp. 1-9.

27. Bumanis, G., Rugele, K., Bajare, D. The Effect of Alkaline Material Particle Size on Adjustment Ability of Buffer Capacity Materials Science (Medziagotyra) 21 (3) 2015: pp. $405-409$.

28. Cheng, H., Lin, K.L., Cui, R., Hwang, C.L., Cheng, T.W., Chang, Y.M. Effect of Solid-To-Liquid Ratios on the Properties of Waste Catalyst-Metakaolin Based Geopolymers Construction and Building Materials 88 2015: pp. 74-83. https://doi.org/10.1016/j.conbuildmat.2015.01.005

29. Subaer van Riessen, A. Thermo-mechanical and Microstructural Characterisation of Sodium-poly (Sialate-siloxo) (Na-PSS) Geopolymers Journal of Material Science 42 (9) 2007: pp. 3117-3123. https://doi.org/10.1007/s10853-006-0522-9

30. Garcia-Lodeiro, I., Fernandez-Jimenez, A., Palomo, A., MacPhee, D.E. Effect of Calcium Additions on N-A-S-H Cementitious Gels Journal of the American Ceramic Society 93 (7) 2010: pp. 1934-1940. https://doi.org/10.1111/j.1551-2916.2010.03668.x

31. Zhang, A., Wang, H., Provis, J.L., Bullen, F., Reid, A., Zhu, Y. Quantitative Kinetic and Structural Analysis of Geopolymers. Part 1. The Activation of Metakaolin with Sodium Hydroxide Thermochimica Acta 539 2012: pp. $23-33$. 